\title{
Tahran Üniversitesi Tıp Bilimleri ve Sağlık Servislerinde 2016-2017 Yıllarında Farsça Olmayan Tıbbi Süreli Yayınların Tezlerdeki Alıntı Analizi
}

\section{Citation Analysis of Non-Persian Medical Periodicals through Theses in 2016-2017 in Tehran University of Medical Sciences and Health Services}

\author{
${ }^{1}$ Hojat Ollah SOLEIMANI, ${ }^{2}$ Setareh SOLEIMANI
}

${ }^{1} \mathrm{PhD}$ of the Department of Knowledge and Information Science, Faculty of Human Sciences, Science and Research Branch, Islamic Azad University Tehran, Iran

${ }^{2}$ BA in General Health, Paramedicine School, Tehran University of Medical Sciences, Tehran, Iran

Hojat Ollah Soleimani: https://orcid.org/0000-0002-8469-0488

Setareh Soleimani: https://orcid.org/0000-0003-2424-5339

\section{Öz}

Amaç: Bu çalışmanın amacı, alıntı yapma yöntemini kullanarak üniversitenin Farsça olmayan süreli yayınlara atıfı dikkate alarak 2016-2017 yıllarında yüksek lisans öğrencilerinin bilimsel davranış modelini anlamaktır.

Materyal ve Metot: Bu çalışmanın metodolojisi tanısalanalitik yöntem olup veriler SPSS20 istatistik program kullanılarak analiz edilir ve nihai rapor WORD kullanılarak hazırlanır.

Bulgular: Toplamda, 21890 kaynaktan 658 tez değerlendirilmiştir. Her tezde ortalama 33,3 kaynakça gösterildi. Sonuçlar, en önemli kütüphane kaynaklarının dergi olduğunu göstermektedir. $\mathrm{Bu}$ nedenle, elektronik kaynaklar sağlanırken dergi derlemesi ihmal edilmemelidir. Kullanılmayan ve yayınlanmamış dergiler koleksiyondan çıkarılmalı ve bunun yerine en çok SCI dizininde yer alan dergiler temin edilmelidir.

Sonuç: Elde edilen sonuçlara göre, çalışmanın ilk hipotezi Farsça olmayan süreli yayınların Farsça olmayan kitaplardan ve diğer kaynaklardan daha fazla alıntılandığı doğrulanmaktadır. Çalışmanın ikinci hipotezi, üniversitenin Farsça olmayan süreli yayınlarının diğer kurum ve kuruluşlardan daha fazla alıntılandığı doğrulanmaktadır. Çalışmanın üçüncü hipotezi, tıp tezlerinin üniversitenin Latin tıp dergilerinden daha fazla alıntılandığı doğrulanmaktadir.

Anahtar Kelimeler: Atıf, atıf analizi, Farsça olmayan tıp dergileri, referanslar, tıp tezleri

\section{ABSTRACT}

Objective : The purpose of this study is to understand the scientific behavior pattern of graduate students in 20162017 citing the non-Persian periodicals of the university using the citation analysis method.

Materials and Methods : The methodology of this study is descriptive-analytical method, and data is analyzed using the statistical software SPSS20 and the final report is prepared using WORD.

Results: Totally, from 21890 references, 658 theses were evaluated. In each thesis, 33.3 references, on average, were cited. The results indicate that the most important library resources are magazines. Therefore, while providing electronic resources, the collection of magazines should not be neglected. Unused and unpublished journals should be removed from the collection and instead, journals should be provided that are most cited in the citation index of science.

Conclusion: According to the results, first hypothesis of the study is confirmed that non-Persian periodicals are cited more than non-Persian books and other references separately. The second hypothesis of the study is confirmed that non-Persian periodicals of the university are cited more than other institutions and organizations. The third hypothesis of the study is confirmed that medical theses are cited more than Latin medical periodicals of the university.

Keywords: citation, citation analysis, medical theses, non -Persian medical periodicals, references
Sorumlu Yazar / Corresponding Author:

Hojat Olah Soleimani

Manager in Daneshshenas Publication Instructor. PhD Professor of the Department of Knowledge and Information Science, Paramedicine School, Tehran University of Medical Sciences. Tehran - Iran

Phone: 09119330489

E-mail: daneshshenas@gmail.com
Yayın Bilgisi / Article Info:

Gönderi Tarihi/ Received:17/09/2018

Kabul Tarihi/ Accepted: 04/12/2019

Online Yayın Tarihi/ Published: 30/06/2020

Atıf / Cited: Soleimani HO, Soleimani S. Citation Analysis of Non-Persian Medical Periodicals through Theses in 2016-2017 in Tehran University of Medical Sciences and Health Services. Online Türk Sağllk Bilimleri Dergisi 2020;5(2):203-209. doi: 10.26453/otjhs.460498 


\section{INTRODUCTION}

Although citation analysis cannot be a direct tool for measuring the quality or importance of the article, it refers to the scientific relevance of the articles and the scope of the document's impact on them. ${ }^{1}$ Articles are cited when published in major magazines in conjunction with research based on experience and human history in the advanced world. ${ }^{2}$ The citation analysis of references allows different types of sources to be used. Also, due to this method, there can the core journals and their half-life can be identified. ${ }^{3}$ For example, In the citation evaluation of the electronic journals collection of Switzerland, which was used to determine the main journals, it was found that $91 \%$ of the articles were from journals, $7 \%$ of books, $1 \%$ of seminars and $1 \%$ of the Internet. Although citations are an important tool for examining the importance of articles, the investigation of the documentation based on the algorithm is more important. Investigating algorithmic citations can be helpful in identifying important articles and presenting profound results. ${ }^{4}$

Latin-printed periodicals in Iranian universities are usually provided at a very high cost. ${ }^{5}$ The number of printed titles of journals and their prices are rising every year. This is contrasted with the relatively modest budget of libraries. Nevertheless, periodicals are considered to be the most vital information materials of libraries, especially academic and specialized libraries. ${ }^{6}$ An academic library is required to provide information. This requires periodic journals to be evaluated in order to purchase magazines that are more important. In other words, in order to be able to meet the most needs with the least budget, it is necessary to research magazines from various aspects. ${ }^{7}$

For this reason, the researcher has been examined Latin periodicals in various aspects. In his dissertation, the researcher examined the extent of using and overlapping of journals in 22 libraries of Tehran University of Medical Sciences. The methodology was survey method. Among1228 titles of the magazine, 836 titles had zero use frequency. Therefore, the first hypothesis of the research was not approved. The volume of overlapping of journals was calculated two to two. Among 242 pairs of libraries, 189 pairs of libraries (78.91\%) were overlapped. Based on the findings, it was suggested that the journals with overlapping and zero-use frequency should be eliminated according to first priority. ${ }^{8}$

In 2016, the researcher reviewed current and reportage journals of the Tehran University Medical Library, and identified, using the Bradford Law and a cost-benefit analysis core main journals. The research hypothesis was based on the use of more than half of the journals by the respondents. In total, during the collection of raw data, 4248 referrals to 611 periodicals from 1998 were conducted and 23341 referrals to 860 periodicals of current and retrospective journals were conducted in 16 libraries while 1096 periodicals of 1965 periodicals were not used even once ( $56.3 \%$ of total periodicals). Also, in this study, 255 titles from the titles used in the previous version of the researcher with zero frequency had zero frequency non-frequent frequency. 36 titles from 58 titles of the core magazines in all investigated libraries overlapped with previous magazines. Total titles in the first area (core area) in all libraries were 66 titles and the number of visits was 1818 times. $^{9}$

In another study, the researcher in 2013 investigated the frequency correlation coefficient of using nonperiodic periodicals of university libraries and their degree of importance from the perspective of faculty members. The methodology was the empirical survey method. The research hypothesis has been confirmed that there is a positive correlation between the number of copies taken over the course of one academic year from non-Persian journals and the degree of importance of journals from the faculty point of view. There were 242 titles from 521 titles of the reviewed journals (46.4\%) with zero use frequency of which 79 titles (15.1\%) were considered as unimportant and insignificant by the faculty. 126 titles (24.2\%) were used more than 10 times. Of these, 71 titles (12.6\%) were considered as very important by the faculty. ${ }^{10}$

As we can observe, the periodicals of the university have been investigated by the researcher in various aspects, including the frequency of use, cost-benefit, and journal overlap, half-life of journals, core journals, Bradford law, faculty opinions and correlation with use frequency of magazines. In this study, in order to complete the research puzzle, information sources have been cited. The final report of this research is in 300 pages with 77 tables and 28 
charts.

The purpose of this study is to understand the scientific behavior pattern of graduate students in 2016-2017 citing the non-Persian periodicals of the university using the citation analysis method provided at references of their theses.

\section{MATERIALS AND METHODS}

One of the objective methods for evaluating journals is to identify patterns of scientific behavior and citation analysis. This method is done in three ways: citation analysis of first-order information resources, citation analysis of second-order information sources, and citation analysis of the title in bibliographies. This is a retrospective study on theses done. The permission was obtained from the units for this study.

Theses were taken in Tehran University of Medical Sciences. Researcher has gotten the theses of all faculties of Tehran University of Medical Sciences include: Schools of Medicine, Allied medical sciences, Nursing and Midwifery, Rehabilitation, Pharmacy, Dentistry etc. The theses were available in the Technical Services section of the Central Library and Documentation Center of University. The author was responsible of this section. So he had easy access to thesis.

In this research, one of the resources of the firstorder was used to evaluate the deep and limited citation analysis (theses). The findings of this research could be used to provide a list of medical information resources and to increase productivity significantly.

In this research, information was collected from university theses. After searching for theses and listing them, each individual resource of each thesis was reviewed. The data collection tool was a special table, primary, secondary and mother lists.

Statistical analysis: The methodology of this study is descriptive-analytical method, and data is analyzed using the statistical software SPSS20 and the final report is prepared using WORD.

In this research, all citations in theses sources were analyzed using citation analysis. One of the characteristics of this method is its practicality.

\section{RESULTS}

In this study, in total, the reference of 658 theses were reviewed which were related to the academic year 2016-2017 of Tehran University of Medical Sciences and Health Services. In total, 7863 articles have been cited by non-Persian journals of the university. In total, the non-Persian journals of Iranian universities in the theses of all libraries of Tehran University of Medical Sciences have been cited 14446 times. Persian journals of Iranian universities have been cited 319 times in the theses of all university libraries. The non-Persian books of Iranian universities have been cited 4594 times in the theses of all university libraries. All books of the university have been cited 4594 times. Persian books of Iranian universities in the theses of all libraries of the university have been cited 1329 times. Persian theses of Iranian universities in the theses of all libraries of the university have been cited 978 times. Other references of Iranian universities in the theses of all libraries of the university have been cited 224 times. Also, the magazines, books, theses and other Persian and non-Persian resources have been cited 21890 times (Table 1).

\section{DISCUSSION AND CONCLUSION}

Science, in general, depends on communication and publishing system. One of the most important factors in scientific writings is the reliability of the information provided in them. Scientific texts will be valid if their contents are cited. This authenticity is specified by inserting citation and referral accurately to them in the text. References cited in scientific publications represent the sources and origins of the thoughts contained in those works. ${ }^{11}$

Since the thesis is the first serious movement of the student during a particular academic year, it can prepare him for use in future research. The information and research validity of the theses are taken into account in two respects: 1.The nature of the research subject 2 . The sources and references used.

Students should search and use texts and resources that are sometimes out of sight for others to find work experience or research evidence.

The nature of the resources (first-hand and secondhand) and the desire to find documents that are difficult to identify and achieve makes it difficult to list the reference list, which is a very valuable resource for knowing specific texts. For this reason, the introduction of bibliographies which use is not only useful but necessary, the list of references for theses is recommended in terms of resources. ${ }^{12}$

The purpose of all services and activities carried out in libraries and information centers includes 
collection, technical services, organization, trusteeship and reference services, and the fulfillment of users' information needs. Accordingly, it is necessary to examine continuous information research due to various aspects, information issues and their productivity. The present plan is also in the same direction and following previous research by the researcher that the purpose of this study is to understand the scientific behavior pattern of graduate students in 2016-2017 citing the nonPersian periodicals of the university using the citation analysis method. This research was conducted in hopes of finding the ways to deliver the best service and at the lowest cost.

In this regard, information topics were examined based on their citation rates. Citation analysis, irrespective of its small negative aspects, is one of the best methods for evaluating the use of information. Today, citation analysis is not only significantly used to measure the impact and quality of scientific works, but also reflects the level of influence of thought on scientists and researchers. ${ }^{12}$ Also, by using this method, we can understand the extent of citation in is used in other sources.

The researchers, based on his previous researches mentioned in the introduction, found new hypotheses that need to be considered. The hypotheses of this research and their results are as follows:

The first hypothesis of the research: Non-Persian periodicals of the university have been cited more than other centers.

Totally, Non-Persian periodicals 14446 times, Persian periodicals 328 times, non-Persian books 4594 times, Persian books 1329 times, theses 978 times and other resources 224 times have been cited. In theses of the academic year 2004 - 2005, different resources have been cited 21899 times. In other words, Non-Persian magazines $65.96 \%$, Persian magazines $1.49 \%$, non-Persian books $20.98 \%$, Persian books $6.06 \%$, Persian theses $4.46 \%$ and other resources $1.02 \%$ have been cited (Table 1). Therefore, the first hypothesis of this research is approved because $65.96 \%$ of the total citations to various sources are related to non-Persian periodicals.

Second hypothesis of the research: The theses of the university have been cited more than Latin periodicals of the university.

As stated in the result of first hypothesis, Iranian non
-Persian periodicals with 14446 citations (65.96\%) among the total citations received the most citation (Table 1). non-Persian magazines of the university with 7863 citations $(35.9 \%)$ have been cited more than other references. Also, the theses with 978 citations received $4.46 \%$ from all citations to various references. Therefore, third hypothesis of the study is not approved.

Questions arising from hypotheses also had the following answers:

What is the number of citations to non-Persian magazines of the university? In total, 629 titles of non-Persian journals have been cited 7863 times. In total, 1153 non-Persian journals have been cited at least once.

How many percent of the titles of university journals were cited at least once? $51.2 \%$ of the titles of nonPersian journal of the university were cited.

How many percent of the books were cited? All Persian books and non-Persian books were cited 536 times. This is equal to $25.7 \%$ of the total citations.

How many percent of the theses were cited? In total, the theses of the academic year 2004-2005 in the libraries of the university were cited 978 times. Given that the total number of citations to all references is 21601 times, the theses were cited $4.5 \%$ of all references (Table 1 ).

How many percent of the citations have been considered to non-existent journal in the university? $54.4 \%$ of all citations to Iranian non-Persian journals have been considered to non-Persian journals of the university.

It is noticeable that there is a clear and logical connection between the amount of citations and the results of previous investigations of the researcher including the frequency of use, cost-benefit, and journal overlap, half-life of journals, core journals, Bradford law, faculty opinions and correlation with use frequency of magazines. Perhaps in the next article you can see details.

Citation analysis is a bibliometric technique of counting citations. Researchers may need to gauge the importance of their publications by this method of citation analysis. ${ }^{13}$ Since any scientific activity requires awareness of previous activities, it is necessary to refer to other studies conducted in the field of citation analysis in Iran including Jahed ${ }^{14}$, Zandi ${ }^{15}$, Saboktakin ${ }^{16}$, Royai $^{17}$, Afshar ${ }^{18}$, Poorsharif $^{19}$, Jamali Mahmoi ${ }^{20}$, Hori ${ }^{21}$, Khaksar ${ }^{22}$, Khosravi $^{23}$, Rabizadeh ${ }^{24}$, Shahmiri ${ }^{25}$. 
The above researchers referred to the library subjects, and this is evident in their researches and their citations to each of the titles are different. This indicates the difference between their productivity. Meanwhile, it is deduced from the research that books and magazines have the most citations, as is the case in the present study.

Conclusion: Overall, 21890 references and 658 theses of the university related to the academic year 2016-2017 have been evaluated. In each thesis, on average, 33.3 references were cited. The results show that the most important print resources of the library are magazines. Therefore, while providing electronic resources, the collection of magazines should not be ignored. According to previous study of the researcher on the periodicals of the university, unused and incited magazines were removed from the collection and instead of them; the magazines were bought which had the most citations in the citation index of science.

Ethics Committee Approval: The permission was obtained from the units for this study. There was no need for the Ethics Committee's Approval.

Conflict of Interest: No conflict of interest was declared by the authors.

Author Contributions: Concept - HOS ; Supervision SS; Materials -HOS, SS; Data Collection and Processing - HOS, SS; Analysis and Interpretation - HOS, SS; Writing - HOS.

Peer-review: Externally peer-reviewed.

Acknowledgement: The authors thank to Medical Librarians of Tehran University of Medical Sciences.

\section{REFERENCES}

1. Furlan JC. A Web-based systematic review traumatic spinal injury comparing the citation classics with the consumers perspectives. J Neurotrauma. 2006;23(2):156-169.

2. Van DH; Henkens K. What Makes a Scientific Paper Influential?-A Citation Analysis. Tindergen Institute Discussion. March 8, 2000. https://papers.ssrn.com/sol3/papers.cfm? abstract_id=250885. Accessed December 29, 2018.

3. Coutial F, Lenoir G. Evaluation d,une collection de Revues: Identification d,un noyau de revues en cancerologie. Revue electroniq Suisse de science de 1, information. Mars3, 2006. http:// campus.hesge.ch/ressi/numero_2_juillet2005/ articles/PDF/RESSI_015_FCGL_Evaluation.pdf Accessed December 29, 2018.

4. Bernstam EV, Herskovic JR. Using Citation Data to Improve Retrieval from MEDLINE. J Am Med Inform Assoc. 2006;13(10)96-105.

5. Soleimani HO. Internet and periodicals of the universities. Educational and research monthly, Kama Information. 2002;3(17): 37-52.

6. Soleimani HO. Internet and periodicals of the universities. Third National Library and Information Conference of Alzahra University, Tehran, Alzahra University. 2002.

7. Soleimani HO. Research in Liberary: Latin periodicals. Educational and research monthly, Kama Information. 2001;2(12):21-31.

8. Soleimani HO. The investigation of use frequency of non-Persian magazines of Tehran University of Medical Sciences and Health Services in 1994-1995 and their overlapping. Master's thesis in Library and Information Science, Faculty of Management and Medical Information, Iran University. 2002.

9. Soleimani HO. Review of current journals and retrospective journals of major libraries of Tehran University of Medical Sciences and Health Services using the utility cost analysis method, Bradford Law and Frequency of Use. Fifth Library and Information Technology Congress of Iran University with Productivity Orienteering. Tehran, Iran University. 2016.

10. Soleimani HO. Frequency correlation coefficient using non-periodic periodicals in major university libraries over 9 months and their degree of importance from the perspective of faculty members of Tehran University of Medical Sciences and Health Services. Quarterly of the book. 2013;30(21):35-45.

11. Davarpanah MR. The status of citation in scientific activities. Quarterly of the book. 2005;6(3):47-57.

12. Riahi Z. The study of the application of applied publications in the librarianship master's theses of tarbiat modares university, Tehran University, Shiraz University and Iran University of Medical Sciences. Master's Degree in Library and Information Science, Faculty of Humanities, Tarbiat Modarres University. 1993.

13. Gupta K. Citation Analysis of Information Research: An International Electronic Journal. 
(2013). Library Philosophy and Practice (ejournal). 1034. 2013;10(4). http:// digitalcommons.unl.edu/libphilprac/1034. Accessed December 29, 2018.

14. Jahed H. Citation analysis of Ph.D. thesis of Shahid Beheshti University of Medical Sciences and Health Services during 1989-1993, Master's thesis of medical library and information science, Faculty of Management and Medical Information, Iran University of Medical Sciences and Health Services.1994.

15.Zandi F. Citation analysis. Social and human magazine of Shiraz University during 1977-1986, Master's Degree in Library and Information Science, Faculty of Literature \& Humanities, Shahid Chamran University, Ahvaz. 1999.

16. Saboktakin N. Citation analysis of Ph.D professional veterinary theses in terms of reference to $\mathrm{Ph} . \mathrm{D}$ professional veterinary theses, Master's Degree in Library and Information Science, Faculty of Humanities, Tarbiat Modarres University. 1995.

17. Royai HR. Citation analysis of Ph.D professional veterinary theses in terms of reference to $\mathrm{Ph} . \mathrm{D}$ professional veterinary theses, Master's Degree in Library and Information Science, Faculty of Humanities, Tarbiat Modarres University. 1997.

18. Afshar M. Comparison and comparison of citations of master's theses of nursing in Iran University of Medical Sciences and Health Services, Shiraz University and Isfahan University during 1991-1994. Master's thesis of medical library and information science, Faculty of Management and Medical Information, Iran University of Medical Sciences and Health Services. 1996.

19.Poorsharif E. Citation analysis of Graduates' dissertations of the Faculty of Basic Sciences during 1995-1997, Master's thesis of medical library and information science, Faculty of Humanities, Tarbiat Modarres University. 1996.

20. Jamali Mahmoomi HR. Interdisciplinary and Interdisciplinary Librarianship and Information Communication Citation, Master's Degree in Library and Information Science, Faculty of Psychology and Educational Sciences, University of Tehran.1999.

21.Horri A. Comparison between citation similarities and index terms similarities in correlation of documents with the common subject, Ph.D thesis, University of Wisconsin, Ohio, USA. 1981.

22.Khaksar M. Citation analysis in Al-Mizan. Master's Degree in Library and Information Science, Faculty of Psychology and Educational Sciences, University of Tehran. 1999.

23. Khosravi Taj HR. Citation analysis of the dissertations of graduate students of Isfahan School of Educational Sciences and Psychology during 1995-1997, Master's Degree in Library and Information Science, Faculty of Psychology and Educational Sciences, Azad University. 1998.

24. Rabizadehfard Z. Investigation of the status of citation in the geographical declarations of the Dehkhoda dictionary, Master's Degree in Library and Information Science, Faculty of Psychology and Educational Sciences, Tehran University. 1999.

25. Shahmiri S A. Analysis of content of articles in agricultural journals in Persian language at agricultural colleges of Iranian universities from the beginning of publication till the end of the year 1996, Master's Degree in Library and Information Science, Faculty of Psychology and Educational Sciences, Tehran University.1999. 


\begin{tabular}{|c|c|c|c|c|c|c|c|c|c|c|c|c|c|c|}
\hline \multicolumn{3}{|c|}{ 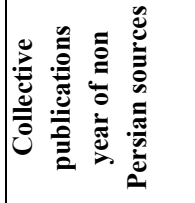 } & 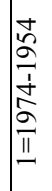 & 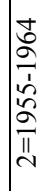 & $\begin{array}{l}\frac{1}{2} \\
\vdots \\
\vdots \\
\vdots \\
0 \\
\text { In } \\
m\end{array}$ & 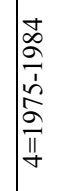 & 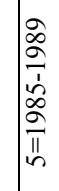 & 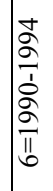 & $\begin{array}{l}\hat{\alpha} \\
\frac{1}{2} \\
\hat{\alpha} \\
\frac{1}{\pi} \\
\frac{1}{n}\end{array}$ & 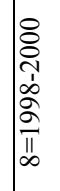 & 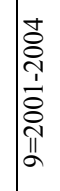 & 光 & 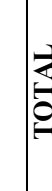 & \\
\hline \multirow{4}{*}{ 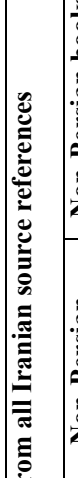 } & \multirow{2}{*}{ 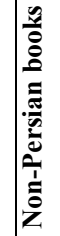 } & $\therefore$ & $\overrightarrow{0}$ & - & $\stackrel{9}{-}$ & 8 & $\begin{array}{l}n \\
n \\
n\end{array}$ & $\stackrel{m}{a}$ & $\underset{I}{ \pm}$ & 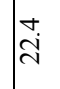 & 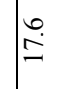 & - & $£$ & \\
\hline & & 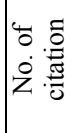 & 6 & F & $\infty$ & 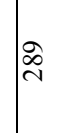 & $\stackrel{\Xi}{r}$ & {$\left[\begin{array}{l}\infty \\
\infty \\
\infty\end{array}\right.$} & ర్ర & בे & 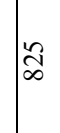 & in & 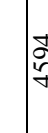 & \\
\hline & \multirow{2}{*}{ 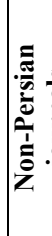 } & $\therefore$ & $N$ & $\because$ & $\ddot{n}$ & $\stackrel{\circlearrowright}{\exists}$ & 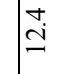 & 2 & $\begin{array}{l}n \\
n \\
n \\
n\end{array}$ & $\stackrel{1}{2}$ & $\begin{array}{l}\infty \\
\ddot{n} \\
\ddot{n}\end{array}$ & $\because$ & $£$ & \\
\hline & & 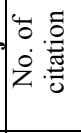 & 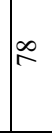 & సิ & $\vec{F}$ & $\widehat{్}$ & 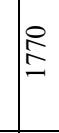 & 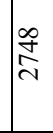 & $\overrightarrow{\widetilde{\pi}}$ & $\underset{\sim}{\stackrel{D}{2}}$ & $\widetilde{\widetilde{N}}$ & in & J & \\
\hline \multirow{2}{*}{ ह } & & $\therefore$ & ' & הิ & $\ddot{\theta}$ & $\bar{i}$ & $\approx$ & $\stackrel{m}{ \pm}$ & 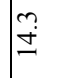 & $\stackrel{1}{2}$ & @̊ & {$\left[\begin{array}{l}\infty \\
\dot{\jmath}\end{array}\right.$} & $£$ & \\
\hline & $\frac{5}{5}$ & 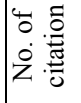 & ' & in & $\sim$ & 0 & $\hat{\imath}$ & $\approx \tilde{n}$ & $\tilde{n}$ & 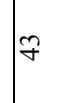 & $\stackrel{0}{+}$ & $\bar{m}$ & 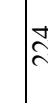 & \\
\hline \multirow{2}{*}{ 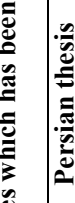 } & & $\therefore$ & $\stackrel{m}{0}$ & $\cong$ & 6 & $m$ & $\mid \begin{array}{l}\infty \\
\stackrel{\Perp}{\underline{I}}\end{array}$ & $\stackrel{+}{\ominus}$ & $\stackrel{2}{2}$ & ¿্ণ & 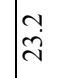 & $\hat{\alpha}$ & $£$ & \\
\hline & & 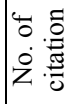 & $m$ & $\cong$ & in & $\vec{\lambda}$ & 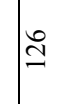 & $\widetilde{\varrho}$ & $\stackrel{\infty}{\beth}$ & ¿্ণি & $\widehat{\widehat{N}}$ & $\infty$ & $\check{a}$ & \\
\hline \multirow{2}{*}{\multicolumn{2}{|c|}{ 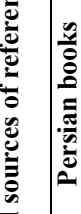 }} & $\therefore$ & $\ddot{\circ}$ & $\stackrel{\bullet}{-}$ & $\stackrel{\sim}{m}$ & $\stackrel{\infty}{\sim}$ & 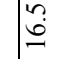 & $\bar{\Xi}$ & $\stackrel{\infty}{\rightarrow}$ & 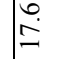 & 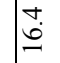 & $\stackrel{?}{F}$ & $£$ & \\
\hline & & 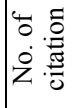 & - & ส & $\mathscr{f}$ & $\stackrel{t}{\stackrel{t}{0}}$ & సి & $\stackrel{\infty}{\infty}$ & $\underset{\sim}{\stackrel{q}{d}}$ & $\cong \tilde{\vartheta}$ & $\frac{\infty}{\sim}$ & $\stackrel{\infty}{\infty}$ & శి & \\
\hline 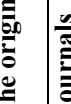 & 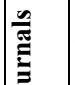 & $\therefore$ & $\bar{i}$ & $\frac{\infty}{m}$ & $\stackrel{ \pm}{\varrho}$ & $\stackrel{g}{\dot{q}}$ & $\stackrel{n}{\beth}$ & $\mid \begin{array}{l}n \\
\infty \\
\infty\end{array}$ & 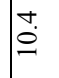 & $\begin{array}{l}0 \\
\dot{\Xi}\end{array}$ & $\stackrel{m}{\infty}$ & $\stackrel{+}{\stackrel{\ominus}{\varrho}}$ & $£$ & \\
\hline . & 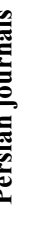 & 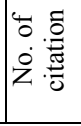 & $r$ & 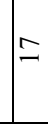 & $\stackrel{m}{m}$ & $\because$ & $F$ & $\stackrel{\infty}{\sim}$ & 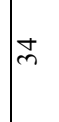 & $\stackrel{\infty}{\leftrightarrow}$ & 8 & m & $\bar{m}$ & \\
\hline
\end{tabular}

